\title{
Anatomy education in Ethiopia - the effect of school background on medical school performance
}

\author{
Abebe Ayalew Bekel (D), Dawit Habte Woldeyes (D), Yibeltal Wubale Adamu (D), \\ Mengstu Desalegn Kiros (D), Shibabaw Tedila Truneh (D), Belta Asnakew Abegaz \\ Department of Human Anatomy, College of Medicine and Health Sciences, Babir Dar University, Babir Dar, Ethiopia
}

\begin{abstract}
Objectives: In Ethiopia, western modern education has been introduced in 1908, though there has been traditional education starting from the entrance of Christianity in Ethiopia in the sixth century. Currently, there are thousands of government and private schools in the country. The objective of this study is to identify who scores well in anatomy in the university; students coming from government or private schools?

Methods: A cross-sectional study design was used to assess the effect of high school background on medical students' performance in anatomy among 120 randomly selected students at Bahir Dar University College of Medicine and Health Sciences.

Results: Anatomy is given for medical students as separate course in regional approach for ten months after they complete premed courses as five hours lecture and one hour practical session per week. Students than take an exam with theoretical and practical parts, after completion of each region. Out of 120 randomly selected students about $64 \%$ joined the university from government schools and the rest were from private schools. From the government school group, only $17 \%$ of the students scored low. However, out of the total private school students $40 \%$ were low scorers. There was a statistically significant correlation between school background and medical student performance in anatomy $(p=0.007)$. The odds of private school students performance in anatomy was 3.22 times lower than those of government school students ( $p=0.007)$
\end{abstract}

Conclusion: Students graduated from government high schools perform better in academics than students graduated from private schools.

Keywords: government school; performance; private school

Anatomy 2019;13(2):122-125 @2019 Turkish Society of Anatomy and Clinical Anatomy (TSACA)

\section{Introduction}

In Ethiopia, western modern education has been introduced in 1908, though there is traditional education starting from the entrance of Christianity in Ethiopia in the sixth century. Currently, there are thousands of government and private schools in the country. Different types of disciplines are taught in various universities with an aim to produce professional clinicians and teachers for medical and allied disciplines. ${ }^{[1]}$ These universities admit their students from both private and government schools that scored the cut point result for admission to higher education. Most of students with the highest score join the medical education as Ethiopian ministry of education announces every year.
Medical training at the Bahir Dar University, College of Medicine and Health Sciences is currently a six years program which is divided into preclinical stage and clinical stage. The preclinical stage encompasses pre-medicine, pre-clinical I and pre-clinical II. The clinical stage is divided into clinical I, clinical II and final year (internship) training. The actual medical training begins in the preclinical departments where the students study the basic medical science subjects, including anatomy, embryology, histology, biochemistry and physiology. ${ }^{[2,3]}$ Anatomy is a very important but difficult subject in medical science. The study of anatomy is one of the most relevant aspects of the pre-clinical training. A sound knowledge in the subject is essential if the medical practitioner 
Table 1

Cross-tabulation of school background and students performance.

\begin{tabular}{lcccc}
\hline School type & High performance & Low performance & Total & p-value \\
\hline Government & 64 & 13 & 77 & 0.007 \\
Private & 26 & 17 & 43 & 120 \\
Total & 90 & 30 & 17 & \\
\hline
\end{tabular}

is going to accurately define and successfully treat the patient. $^{[4]}$

During these stages of study students fail more in anatomy than in histology, embryology, biochemistry and physiology, knowing predictors of academic failure and success is important for medical schools that are trying to ensure high completion rates and develop support mechanisms for students with inadequate performance. ${ }^{[5]}$ A recent study showed that those who perform poorly in the early years of medical school, for whatever reason, might be at an increased risk for subsequent professional misconduct. ${ }^{[6]}$

Despite a multitude of social, academic, and emotional stressors, most students successfully cope with a complex new life role and achieve academic success. Other students are less able to successfully manage this transition and, sooner or later, decide to withdraw themselves, or face dismissal by the medical school. ${ }^{[7]}$

In Ethiopia, the effect of student's school background on medical students' performance in Anatomy has not been assessed yet. Hence, the objective of this study is to identify who scores well in anatomy; students coming from government or private schools? Accordingly, the result of this particular research will help policy makers to give possible suggestions and decisions to the concerned bodies.

\section{Materials and Methods}

A cross sectional study design was used to assess the effect of student's school background on medical students' performance in Anatomy at Bahir Dar University College of Medicine and Health Sciences, Bahir Dar, Ethiopia. To carry out this study 120 randomly selected students were used, who join medical school for the first time after completion of 12 th grade.

After informed verbal consent was taken from participants, data was collected using a structured questionnaire. The data obtained were checked for clarity and consistency before analysis, IBM SPSS Statistics for Windows (Version 22.0, Armonk, NY, USA) was used for statistical analyses and values of $\mathrm{p}<0.05$ were considered statistically significant. Descriptive statistical analysis was performed. Logistic regression was used to assess the correlation between student's school background and medical students' performance in anatomy.

\section{Results}

A total of 120 students, in the age range of 19-21 years, were randomly selected to assess the effect of student's school background on medical students' performance in anatomy at the Bahir Dar University College of Medicine and Health Sciences. Out of the total study subjects, 81 (67.5\%) were males and 39 (32.5\%) were females. From the randomly selected study participants,

Table 2

SPSS output of logistic regression showing the strength of correlation between school type and performance of students.

\begin{tabular}{lcccccccc}
\hline & & & & & & \multicolumn{2}{c}{$95 \%$ CI for Exp (B) } \\
\cline { 6 - 9 } Variables & B & SE & Wald & Significance & Exp (B) & Lower & Upper \\
\hline School type & 1.169 & .436 & 7.199 & .007 & 3.219 & 1.37 & 7.561 \\
Constant & -1.594 & .304 & 27.452 & .000 & .203 & & \\
\hline
\end{tabular}

B: unstandardized beta; Cl: confidence interval; SE: standard error. 
$77(64.2 \%)$ of them joined the university from government schools and 43 (35.8\%) from private schools; 90 $(75 \%)$ were high scorers, whereas $30(25 \%)$ of them were low scorers. Of the total of government school students 64 (83\%) scored high and 13 (17\%) scored low. 26 (60\%) of the private school students were high scorers whereas the remaining 17 (40\%) were low scorers. The odds of private school students performance in anatomy was 3.22 times lower than those of government school students $(\mathrm{p}=0.007)$ (Tables $\mathbf{1}$ and 2).

\section{Discussion}

Anatomy is given for medical students as separate course in regional approach in parallel with histology, embryology, biochemistry and physiology for ten months after they complete pre-med courses. During this period, the students study anatomy with five hours lecture and one hour practical session per week and take an exam after the completion of each region. The exam has both theoretical and practical parts. The theoretical part usually has multiple choices, true/false, matching; fill the blank spaces, and easy questions. The practical part is carried out on cadavers to assess student's skill of dissection. Finally, at the end of the 10th month, they take the final exam which has written and oral parts. The written exam has multiple choice questions from all regions. The oral exam is on models and cadavers and is done by external examiners who come from other universities. After all these activities, students' performance in anatomy is evaluated using the summation of these exams. If student scores more than or equal to 70 , it is considered as high score and less than 70 is low score in the context of our university.

The study sought to establish the relationship between student's school background and medical students' performance in anatomy. Private school students have higher test scores than government school students in higher education entrance exam. However, the opposite is true in the university. Most of high scorers are students from government schools. This is supported by our current study which depicted that from the total of government school students only $17 \%$ of them are low scorers. Conversely, from the total of private school students, $40 \%$ of them are low scorers. Hence, there is statistically significant correlation between student's school background and medical students' performance in anatomy $(\mathrm{p}=0.007)$ (Tables 1 and 2). The odds of private school students' performance in anatomy was 3.22 times lower than that of government school students $(\mathrm{p}=0.007)$
(Table 2). This is supported by a study done in Australia which describes that students who graduated from private schools do less well during their first year at university than other students. ${ }^{[7]}$ This variation can be due to the fact that private schools have better infrastructure required for the physical and mental development of the child. They can help with the required facilities for the students to learn their lessons in a better way. ${ }^{[8]}$ This attributes also seen in a study conducted in India and Spain. ${ }^{[9,10]}$

Having these advantages over government schools, private school students score more than government school students in higher education entrance exam. However, as these students join the university, they have equal opportunities in resource allocation with the government school students. Consequently, most students from the government schools score more than those from the private schools in the university as this study shows. The ministry of education of Ethiopia has to use this study as input and equip government schools with materials and experienced teachers to enable more students to join the university from government schools.

\section{Conclusion}

The study investigated the relationship between students' school background and medical students' performance in anatomy. The findings of this study show that students who graduated their high school from government schools perform better in academics than students graduated from private schools.

\section{References}

1. Banu LA, Shomsher AM. Views of teachers regarding course contents of anatomy in post graduate MD internal medicine curriculum. Bangladesh Journal of Anatomy 2009;7:55-61.

2. Iyawe VI, Ebojele FO. Performance of 300 level medical students of the University of Benin in the second professional MBBS degree examinations: a ten years retrospective study. Journal of Medicine and Biomedical Research 2016;15:49-54.

3. Esom EA, Eze JN, Ozoemena OFN, Ezepue UF. Factors that affect medical students' performance in anatomy in the University of Nigeria. Orient Journal of Medicine 2010;1:6- 10 .

4. Pal S, Pal M. Factors affecting the performance of students in anatomy: a case study. Indian Journal of Applied Research 2013;3: 360-1.

5. Maslov Kruzicevic S, Barisic KJ, Banozic A, Esteban CD, Sapunar D, Puljak L. Predictors of attrition and academic success of medical students: a 30-year retrospective study. PLoS One 2012:7: e39144.

6. Yates J, James D. Risk factors at medical school for subsequent professional misconduct: multicentre retrospective case-control study. BMJ 2010;340:c2040. 
7. Win R, Miller PW. The effects of individual and school factors on university students' academic performance. Australian Economic Review 2005;38:1-8

8. Pal Y, Patel T. A study of educational achievement of government and non government school students in context to area. International Education and Research Journal 2016;2:139-42.

ORCID ID:

A. A. Bekel 0000-0002-5853-2953; D. H. Woldeyes 0000-0002-4922-9928;

Y. W. Adamu 0000-0002-9307-4548; M. D. Kiros 0000-0002-7120-4671;

S. T. Truneh 0000-0003-0849-0772; B. A. Abegaz 0000-0002-6345-2018
9. Goyal S, Pandey P. How do government and private schools differ? [Available on the internet] [http://2010.economicsofeducation.com/ user/pdfsesiones/042.pdf]

10. Mancebon MJ, Calero J, Choi A, Ximénez-de-Embún DP. The efficiency of public and publicly subsidized high schools in Spain: evidence from PISA-2006. J Oper Res Soc 2012;63:1516-33.

Correspondence to: Abebe Ayalew Bekel, MSc

Department of Human Anatomy, College of Medicine and Health Sciences, Bahir Dar University, P. O. Box: 79, Bahir Dar, Ethiopia

Phone: +251918040350

e-mail: abe3a16b@gmail.com

Conflict of interest statement: No conflicts declared.

This is an open access article distributed under the terms of the Creative Commons Attribution-NonCommercial-NoDerivs 3.0 Unported (CC BY-NC-ND3.0) Licence (http://creativecommons.org/licenses/by-nc-nd/3.0/) which permits unrestricted noncommercial use, distribution, and reproduction in any medium, provided the original work is properly cited. Please cite this article as: Bekel AA, Woldeyes DH, Adamu YW, Kiros MD, Truneh ST, Abegaz BA. Anatomy education in Ethiopia - the effect of school background on medical school performance. Anatomy 2019;13(2):122-125. 